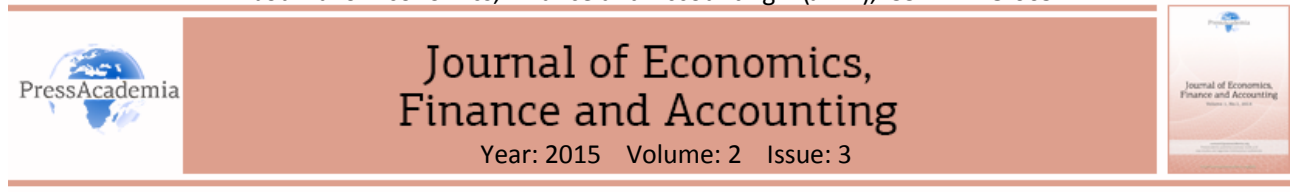

\title{
NECESSITY OF ACCOUNTING AND FINANCE COURSES IN TOURISM EDUCATION AT UNDERGRADUATE LEVEL
}

\section{DOI: 10.17261/Pressacademia.2015312964}

\author{
Ahmet Kaya', Filiz Angay Kutluk ${ }^{2}$, Nilufer Tetik ${ }^{3}$ \\ 'AkdenizÜniversitesi, ahmetkaya@akdeniz.edu.tr \\ ${ }^{2}$ Akdeniz Üniversitesi, angay@akdeniz.edu.tr \\ ${ }^{3}$ Akdeniz Üniversitesi, niltetik@akdeniz.edu.tr
}

\section{Keywords}

Tourism management, tourism education, accounting-finance education, accounting courses, finance courses.

\section{JEL Classification M10, M40, M41}

\begin{abstract}
The people who will get bachelor's degree in tourism should be equipped with necessary accounting and finance knowledge for analyzing and decision-making, besides the core knowledge. The purpose of this study is to analyze the necessity of accounting and finance courses in the curriculums of undergraduate schools related with tourism education and making suggestions. A survey is conducted to 2 different undergraduate tourism programs' students about their opinions about the efficiency of accounting and finance courses they get in their education terms. According to the results, core courses about accounting and finance are in the curriculum, but the number of the courses related to decision making is still not sufficient, even it is better than before. Students think that General Accounting, Cost Accounting, Managerial Accounting and Cost Control in Tourism Establishments should be taught mostly in Accounting-Finance courses group.
\end{abstract}

\section{LISANS DÜZEYINDEKi TURIZM EĞiTiMINDE MUHASEBE VE FINANSMAN DERSLERININ YERI VE ÖNEMi}

\section{Anahtar Kelimeler \\ Muhasebe dersleri, finansman dersleri, turizm İşletmeciliği, turizm Eğitimi, muhasebe-finansman eğitimi.}

\author{
JEL Sınıflandırması \\ M10, M40, M41
}

\begin{abstract}
ÖZET
Turizmle ilgili eğitim veren lisans düzeyindeki yüksekokul ve fakültelerden mezun olanların, turizmle ilgili temel bilgiler yanında, analiz ve karar vermede gerekli muhasebe ve finansman bilgileriyle donatılmış olarak yetiştirilmeleri gerekir. $\mathrm{Bu}$ çalışmanın amacı, Türkiye'de turizmle ilgili eğitim veren lisans düzeyindeki yüksekokul ve fakültelerin ders programlarında yer alan muhasebe ve finansman derslerinin durumunu karşılaştırmalı bir şekilde inceleyerek önerilerde bulunmaktır. Ayrıca turizmle ilgili 2 ayrı lisans bölümündeki öğrencilere anket yapılarak, eğitimöğretim dönemlerinde aldıkları muhasebe ve finansman derslerinin yeterliliği konusundaki görüşleri analiz edilmiştir. Sonuçlara göre muhasebe-finansmanla ilgili temel derslerin programlarda yer aldığı, ancak eskiye göre daha iyi olsa da, karar almaya yönelik derslerin halen yeterli olmadığı görülmektedir. Öğrencilerin en çok okutulması gerektiğini düşündükleri muhasebe-finansman dersleri, sırasıyla Genel Muhasebe, Maliyet Muhasebesi, Yönetim Muhasebesi ve Turizm İşletmelerinde Maliyet Kontrolü dersleridir.
\end{abstract}




\section{GiRiş}

Küreselleşme ve bilgi teknolojilerindeki gelişmeler, işletmeler arası rekabeti arttırmakta ve stratejik kararlar alabilme becerisine sahip çalışanların rolü, daha da önem kazanmaktadır. Turizm sektörü bu gelişme ve rekabetten en çok etkilenen sektörlerden biri olup ülkemizde turizmin gelişimi ve gelirlerindeki artış 1980 yılından sonra ivme kazanmıştır. Bu gelişim aynı zamanda turizm alanında eğitimli eleman gereksinimini de artırmıştır. Bu gelişimle birlikte turizm faaliyetine katılanların seyahat, konaklama, yeme-içme ve çeşitli sosyal ihtiyaçlarının karşılanmasının yanında, sektördeki işletmelerin karlılıklarının ve sürekliliklerinin sağlanması da önemli hale gelmiştir. Bu bağlamda özellikle üst ve orta düzey işletme yöneticilerinin satışlar, faaliyetler ve maliyetleri iyi analiz edilebilmeleri ve doğru kararlar verebilmeleri için yeterli düzeyde muhasebe ve finansman bilgisine intiyaçları olacaktır. Yaşanan gelişmeler ile finansal nitelikli bilgiyi üretmesi sebebiyle muhasebenin önemi gün geçtikçe artmakta ve bu durum, eğitim sırasında muhasebe bilgisinin kazandırılmasını önemli ölçüde gerekli kılmaktadır.

Turizm sektörünün, eğitimci ve üst düzey yönetici ihtiyacı, lisans düzeyinde eğitim veren turizmle ilgili farklı isimlerdeki yüksekokullar ve fakülteler tarafından karşılanmaktadır (Akoğlan Kozak, 2009, s. 2). Lisans düzeyinde turizm eğitiminde temel amaç, turizm sektörüne bilgili ve yetkin bireyler yetiştirmektir. Turizm sektörünün ekonomiye katkısının maksimize edilebilmesi için turizmle ilgili eğitim veren lisans düzeyindeki yüksekokul ve fakültelerde öğrenim görecek olanların, turizmle ilgili temel bilgiler yanında analiz ve karar vermede gerekli muhasebe ve finansman bilgileriyle donatılmış olarak yetiştirilmeleri gerekir. Eğitim sırasında muhasebe bilgisinin kazandırılması diğer becerilerin ve değerlerin kazandırılmasında önemli bir yol gösterici olacaktır (Subaşı ve Demir, 2009, s. 128). Muhasebe ve finansman dersleri kariyer başarısını önemli ölçüde etkileyen, müfredatın öncelikli derslerindendir (Chung, 2000, s.485). Gelişmelere uyum sağlayabilen, işletme yönetiminin karar alma aşamasında yardımcı olacak, işletmenin konumunun korunması ve gelişmesi için doğru kararlar alınmasını gerektiren muhasebe ve finansman bilgisini anlama ve kullanma becerisine sahip çalışanlar, işletmenin amaçlarına ulaşması için kilit rol oynayacaktır. Muhasebe ve finansman bilgisi, turizm sektöründeki işletmelerin sadece muhasebe departmanında değil, her departmanın planlama, maliyet, fiyatlandırma ve karar alma sürecinde gereklidir. Bu yüzden, İşletme Fakültesi'ndeki kadar muhasebefinansman dersleri çeşitliliği olmasa da, turizmle ilgili lisans düzeyinde eğitim veren yüksekokul ve fakültelerin programlarında da turizm bilgisi yanında sektörün devamlılığı ve geleceği ile ilgili doğru kararlar alınmasında yol gösterici olacak muhasebe-finansman bilgisini verecek temel dersler olmalıdır.

Bu çalışmanın amacı, Türkiye'de turizmle ilgili eğitim veren lisans düzeyindeki yüksekokul ve fakültelerin ders programlarında yer alan muhasebe ve finansman derslerinin durumunu karşılaştırmalı bir şekilde inceleyerek önerilerde bulunmaktır. Ayrıca turizm sektöründe staj yapmış olan öğrencilerin eğitim-öğretim dönemlerinde aldıkları muhasebe ve finansman derslerinin yeterliliği konusundaki görüşleri analiz edilmiştir. Mevcut durum, muhasebe ve finansman bilgisinin yeterliliği açısından yorumlanıp durumun geliştirilmesi için öneriler sunulmuştur. 
Çalışma, bundan sonraki kısımda, sırasıyla konuyla ilgili çalışmaların yer aldığı Literatür Araştırması, amaç, yöntem ve katılımcıların özelliklerinin anlatıldığı Araştırmanın Amacı ve Yöntemi, analiz sonuçlarının tablo ve yorumlarının yer aldığı Araştırmanın Bulguları ve Sonuç bölümleriyle ele alınmıştır.

\section{LITERATÜR ARAŞTIRMASI}

Christou (1999), Yunanistan'daki turizm eğitim sistemini incelediği çalışmasında, turizm eğitimi alıp son üç yıl içinde mezun olmuş olanların, aldıkları turizm eğitimi ve edindikleri bilgi ve becerileri gerçek çalışma ortamında uygulayıp uygulamadıkları ile ilgili görüşlerini almıştır. Mezunların çoğu, gerçek çalışma ortamında, yeterli teorik bilgi ve uygulama becerisi kazandıklarına inandıklarını belirtmişlerdir (s.687). Çalışmalarında gerekli bilgi ve beceriyi edindikleri iş̧letme grubundaki tek dersin, muhasebe olduğunu belirtmişlerdir. Çoğunluğu, bu dersin içeriğinin daha detaylı olmasını tercih edeceklerini ifade etmişlerdir (s. 688).

Akoğlan Kozak ve Kozak(2000)'ın seyahat acenteciliği eğitimi veren lise, önlisans ve lisans düzeyindeki eğitim kurumlarının ders programlarında yer alan derslerin, seyahat sektörünün ihtiyaçlarını ne ölçüde karşıladığını değerlendirmek için yaptıkları çalışmada, okulların ders programları karşılaştırması sonucunda seyahat acenteciliği bölümlerinde okutulan derslerin önemli bir kısmının talep edilen dersleri karşıladığı görülmüştür. Lisans düzeyindeki yüksekokul ve fakültelerin, talep edilen derslerin önemli bir kısmını programlarında bulundurdukları, önlisans düzeyindeki okulların okutulan dersler yönüyle beslenmesi gerektiği, lise düzeyindeki okulların ise sektördeki istihdam alanları için gerekli olan dersler konusunda yeterli oldukları ortaya çıkmıştır (s. 66).

Çetin (2005)'in lisans eğitimi alan turizm öğrencilerinin staj süresince eğitim-öğretim programında yer alan derslerden daha çok hangilerinden yararlandıklarını ve yine bu derslerin sınıf, cinsiyet, çalışma statüsü, departman, otelin yıldızı ve staj süresi değişkenlerine göre bir farklılık gösterip göstermediğini test ettiği çalışmanın sonucuna göre stajyerlerin stajları süresince en çok, Bilgisayar, Resepsiyon-Ön Büro Yönetimi, Yiyecek-içecek Yönetimi, Yabancı Dil ve Muhasebe derslerinden; en az ise, Türk Vergi Sistemi ve Uygulamaları; Fiziksel Planlama, Turizm Mevzuatı ve Finansman derslerinden yararlandıkları saptanmıştır (s. 167). Öğrencilerin sınıflara, statülerine ve cinsiyetlerine göre dağılımları ile çalıştıkları otelin yıldızı ile yararlandıkları dersler arasında anlamlı bir ilişki bulunduğu, ayrıca, resepsiyon-ön büro, restoran ve bar, kat hizmetleri, muhasebe ve mutfak ile staj çalışmaları süresince yararlanılan derslere ilişkin bulgular arasında anlamlı bir ilişkinin bulunduğu ortaya çıkmıştır ( s. 168).

Gürbüz ve Dağdeviren (2007), lisans düzeyinde turizm eğitimi veren kurumların amacının turizm işletmelerine yöneticiler yetiştirmek olduğu görüşünden yola çıkarak söz konusu amaç ile ders programları arasındaki ilişkiyi incelemişlerdir. Çalışmanın sonucuna göre kurumların ders programları birbirinden önemli ölçüde farklıdır. Yüksekokul ve fakültelerde öğretim elemanlarının branşları ile girdikleri dersler genellikle birbiriyle uyumlu olup ders programlarının farklılığının sebebiyle ilgili başta belirtilen amaca standart bir eğitim ve tarzda değil birçok farklı şekilde ulaşılabileceği düşüncesi ağırlık kazanmaktadır. Lisans düzeyinde turizm eğitiminden maksimum yararın sağlanmasının, 
nelerin okutulması gerektiği sorunundan çok, mevcut derslerin en iyi şekilde ve en iyi koşullarda nasıl yürütüleceğine cevap aranmasından geçtiği ifade edilmiştir (s. 166).

Tetik ve Kınay (2007)'ın turizm eğitimi veren 4 yıllık yüksekokul ve fakültelerde muhasebe ve finansman konusundaki mevcut eğitim-öğretim durumunu tespit etmek amacıyla yaptıkları çalışmaların sonucunda Türkiye' de 4 yıllık turizm eğitimi veren lisans düzeyindeki tüm yüksekokul ve fakültelerde Genel Muhasebe I-II, Konaklama veya Seyahat İşletmeleri Muhasebesi, Finansal Yönetim ve Yatırım Proje Analizi derslerinin verildiği, bazı yüksekokul ve fakültelerde de Bütçeleme ve Maliyet Kontrolü, Yönetim Muhasebesi, Finansal Tablolar Analizi, Bilgisayarlı Muhasebe ve Maliyet Muhasebesi derslerinin verildiği ortaya çıkmıştır. yüksekokul ve fakültelerde verilen muhasebe grubu derslerin ortalama kredi/saati 2,86, finansman grubu derslerin ortalama kredi/saati ise 2,66 oranındadır. Turizm sektöründe farklı departmanlarda çalışan mezunlara, eğitim-öğretim döneminde aldıkları muhasebe ve finansman derslerinin yeterli olup olmadığı konusunda yapılan anket sonucunda, lisans programlarında verilen muhasebe ve finansman derslerinin yeterli olmadığı görüşünde oldukları tespit edilmiştir. Özellikle yönetim, yiyecek-içecek, muhasebe ve önbüro departmanlarında çalışanlar, muhasebe ve finansman derslerinin arttırılmasını ve içeriğinin genişletilmesini önermişlerdir.

Wang ve diğ. (2010)'nin Avustralya'da turizm eğitimi veren öncü üniversitelerin ders programlarında yer alan konuların içerik analizi ve turizm eğitimi veren öğretim elemanları ile turizm sektöründe çalışan profesyonellerinin bu konular üzerindeki görüşlerini belirlemeyi amaçlayan anket çalışmalarının sonucuna göre, öğretim elemanları ve sektördeki profesyoneller arasında, Muhasebe ve Finansman alanlarıyla ilgili büyük görüş farklılığı vardır. Turizm sektörü profesyonelleri, muhasebe ve finansman alanlarına yüksek derecede önem verirken, turizm eğiticileri aynı derecede önem vermemektedir (s. 11).

Uyar ve Yelgen (2012)'in konaklama işletmelerinin muhasebe eğitiminden beklentilerini tespit etmek amacıyla 5 yıldızlı otellerin muhasebe yöneticileriyle yaptıkları ankette, mevcut muhasebe personelinin eğitim durumu değerlendirilmiştir. Sonuç olarak, 12 ay açık olan oteller dışında 6 ay faaliyet gösteren otellerde, birkaç personel dışında alt kadronun her yıl değiştiği, yeni gelen personelin bilgisiz olmasından dolayı hizmet içi eğitimlerle mevzuat konusundaki yeterlilikle yeni gelişmelerin takibinin sağlanmaya çalıştığı ortaya çıkmıştır (s.344). Muhasebe müdürlerinin çoğu muhasebe derslerinin içeriğinin belirlenmesinde konaklama işletmelerinin taleplerinin dikkate alınmasını, bilgisayarlı muhasebe derslerine gereken önemin verilmesini ve muhasebede kullanılan belgeleri ve düzenlenmesinin gösterilmesi gerektiği isteklerini belirtmişlerdir. Anketin bir başka sonucu da, muhasebe departmanındaki potansiyel eleman eksikliğinden dolayı yüksekokul ve fakültelerde öğrencilerin muhasebe konusunda bilgilendirilip özendirilmesi gereğidir.

Türkeri (2014), 1992, 2002 ve 2012 yıllarında Turizm Bakanlığı'nın gerçekleştirdiği “Turizm Eğitimi Konferans" larında yükseköğretim turizm eğitimi sorunları ile ilgili yapılan çalışmaları incelemiştir. Ulaştığı sonuçlardan biri, ders müfredatı ile sektör arasında uyum oluştuğunun görülmesidir ve ders müfredatlarının uyumlu olmasının, staj eğitimine giden öğrencilerin okulda öğrendikleri teorik bilgilerini zaman kaybetmeden sektörde uygulayabilme imkanını sağlayacağı düşünülmektedir. Ancak, yükseköğretim turizm 
bölümlerinin ders programlarında birliktelik sağlanamamasının yatay ve dikey geçiş yapan öğrencileri tekrar aynı dersi farklı isimle almasına neden olmasından dolayı, ders programlarında akredite edilmesinin bu sorunun önüne geçilmesinde etkili olacağı sonucuna ulaşılmıştır (s. 9).

\section{ARAŞTIRMANIN AMACI VE YÖNTEMi}

Bu çalışmanın amacı, Türkiye'de turizmle ilgili eğitim veren lisans düzeyindeki yüksekokul ve fakültelerin ders programlarında yer alan muhasebe ve finansman derslerinin durumunu karşılaştırmalı bir şekilde incelemektir. Bu amaç doğrultusunda, ilk aşamada, Devlet, Özel ve Vakıf Üniversitelerinde 2014 ÖSYM Yerleştirme Kılavuzu'nda yer alan Türkiye'deki turizmle ilgili lisans düzeyindeki tüm Fakülte ve Yüksekokulların ders programlarında yer alan muhasebe ve finansman dersleri, kredi / saat ve içerik bazında incelenip karşılaştırılmıştır. İkinci aşamada, Akdeniz Üniversitesi ve Alanya Alaaddin Keykubat Üniversitesinin turizmle ilgili lisans bölümlerindeki 4. Sınıf öğrencilerine anket yapılarak eğitim-öğretim dönemlerinde aldıkları muhasebe ve finansman derslerinin yeterliliği konusundaki görüşleri analiz edilmiştir. Araştırmada birden fazla staj yapmış öğrencilerin görüşleri alınmak istendiği için araştırmanın evrenini Akdeniz Üniversitesi Turizm Fakültesi Turizm İşletmeciliği bölümü ile Alanya Alaaddin Keykubat Üniversitesi İşletme Fakültesi Turizm İşletmeciliği bölümünün 4. Sınıf öğrencileri oluşturmaktadır (öğrenci görüşlerinin alındığı dönemde Alanya Iş̧letme Fakültesi Turizm İşletmeciliği bölümü, Akdeniz Üniversitesi'ne bağlıydı). Bu bölümlerde kayıtlı olan öğrenci sayısı toplam 396 olup 141 öğrenciye ulaşılmıştır. Anketlerin geri dönüş oranı \% 35'tir.

$\mathrm{Bu}$ araştırma durum saptamaya ve betimlemeye yönelik bir araştırmadır. Araştırmada veri toplama yöntemi anket yöntemidir. Anket verilerinin analizinde SPSS 16.0 paket programı kullanılmıştır. Veriler, frekans analizi ve çapraz tablo yöntemleriyle analiz edilip yorumlanmıştır.

\section{ARAŞTIRMANIN BULGULARI}

\subsection{Lisans Düzeyinde Verilen Muhasebe ve Finansman Derslerinin Analizi}

2014 ÖSYM Yerleştirme Kılavuzunun incelenmesi sonucunda, 60 Üniversitenin, 28 Turizm Fakültesi, 11 Turizm İşletmeciliği ve Otelcilik Yüksekokulu, 8 Uygulamalı Bilimler Yüksekokulu, 7 İşletme Fakültesi, 4 İktisadi ve İdari Bilimler Fakültesi, 3 Turizm ve Otelcilik Yüksekokulu, 2 Ticari Bilimler Fakültesi, 1 iktisat Fakültesi, 1 İktisadi ve İdari Sosyal Bililer Fakültesi, 1 Uygulamalı Teknoloji ve İşletmecilik Yüksekokulu ve 1 Uygulamalı Bilimler Fakültesi olmak üzere 67 Fakülte veya Yüksekokulunda, 75 adet bölümde turizmle ilgili lisans düzeyinde eğitim verilmekte olduğu tespit edilmiştir. Bölümler incelendiğinde, "Turizm İşletmeciliği", "Turizm İşletmeciliği ve Otelcilik" ile "Turizm ve Otel İşletmeciliği" bölümleri "Turizm Işsletmeciliği" grubu altında; Seyahat İşletmeciliği ile Seyahat İşletmeciliği ve Turizm Rehberliği bölümleri "Seyahat işsletmeciliği " grubu altında; Konaklama İşletmeciliği, Turizm ve Otelcilik ile Otel Yöneticiliği bölümleri "Konaklama İşletmeciliği" grubu altında ele alınmıştır. 75 adet bölümün 48'i Turizm Işsletmeciliği, 8'i Seyahat Işletmeciliği ve 19'u Konaklama işletmeciliği bölümleridir. Turizm Rehberliği, Gastronomi 
ve Mutfak Sanatları ile Yiyecek ve içecek İşletmeciliği bölümleri analize alınmamıştır. Ayrıca 6 tane bölümün ders planı ve içeriklerine ulaşılamamıştır.

Turizmle ilgili lisans düzeyinde eğitim veren bölümün ders programları incelenip Turizm İşletmeciliği, Seyahat İşletmeciliği ve Konaklama İşletmeciliği bölümlerine göre ders dağılımları, çalışmada temel alınan derslerin kredi/saatine göre Tablo 1'de gösterilmiştir.

Tablo 1: Turizmle ilgili Lisans Düzeyinde Eğitim veren Bölümlerin Muhasebe-Finansman Ders Dağılımı

\begin{tabular}{|l|c|c|c|c|c|c|c|c|c|}
\hline \multicolumn{1}{|r|}{ Bölümler } & \multicolumn{3}{|c|}{ Turizm } & \multicolumn{3}{c|}{ Seyahat } & \multicolumn{3}{c|}{ Konaklama } \\
\hline & 2 & 3 & 4 & 2 & 3 & 4 & 2 & 3 & 4 \\
\hline Muhasebe* & 3 & 24 & 5 & & 5 & & & 8 & \\
\hline Genel Muhasebe I & 1 & 12 & & 2 & 1 & & 1 & 3 & \\
\hline Genel Muhasebe II** & 2 & 14 & & 2 & 1 & & 1 & 3 & \\
\hline Maliyet Muhasebesi*** & 1 & 11 & 1 & & 1 & 1 & & & 1 \\
\hline Finansal Tablolar Analizi & 4 & 6 & & 1 & & & 1 & 1 & \\
\hline Yönetim Muhasebesi & 2 & 12 & & & 1 & 1 & 1 & 2 & 1 \\
\hline Turizm İşletmelerinde & 6 & 11 & 3 & & 1 & & & 1 & \\
\hline Yatırım Proje Analizi & 4 & 12 & 1 & 3 & 1 & & 3 & 2 & \\
\hline Finansal Yönetim & 5 & 16 & & 1 & 4 & & 1 & 5 & \\
\hline İşletme Finansmanı & 1 & 6 & & & & & & & \\
\hline Konaklama/Seyahat/Turizm & 7 & 20 & 1 & 1 & 2 & & 3 & 4 & 1 \\
\hline
\end{tabular}

*Bazı bölümlerde tek bir yarıyılda olan "Muhasebeye Giriş", “Finansal Muhasebe" v.b. gibi farklı isimlerle ifade edilen derslerin içeriği yaklaşık olarak birbirine benzediği için "Muhasebe" adı altında toplanmıştır.

**Dönemsonu Muhasebe Iş̧lemleri isimli 3 adet ders, Genel Muhasebe II'ye dahil edilmiştir.

***1 adet dersin adı "Maliyet ve Yönetim Muhasebesi” olup bu gruba dahil edilmiştir.

Finansal kurumlar, Pazarlar ve Araçlar, Finansta Hesaplama Metotları, Finansal Modelleme, Finansal Piyasalar, Türev Piyasalar ve Ürünler, Uluslar arası Muhasebe Standartları v.b. isimli tek bölümde olup diğer bölümlerde olmayan bazı seçmeli dersler, içerikleri biraz farklı olduğu için tablodaki derslere dahil edilmemiştir.

Tablo 1'de görüldüğü gibi Muhasebe veya Genel Muhasebe I ve Genel Muhasebe II dersleri neredeyse bütün bölümlerde olup (Bazı bölümlerde "Konaklama Muhasebesi" olarak yer aldığı için "Genel Muhasebe" grubunda gösterilmemiştir) zorunlu ders kapsamındadır. Konaklama/Seyahat/Turizm Işletmeleri Muhasebesi, Finansal Yönetim, Turizm İşletmelerinde Maliyet Analizi/Kontrolü-Bütçe ve Yatırım Proje Analizi dersleri, 3 ayrı grupta da yer almakta ve özellikle Turizm Işsletmeciliği grubunda daha çok verilmektedir. Bölümlerde muhasebe-finansmanla ilgili temel derslerin verildiği görülmektedir. Ancak karar almaya yönelik Finansal Tablolar Analizi, Yönetim Muhasebesi v.b. derslerin oranı, Tetik ve Kınay (2007)'ın çalışmalarındaki sonuca göre biraz yükselmiş olsa da halen yeterli değildir. 
Tabloda yer almayan dersler de göz önüne alındığında ders çeşitliliği artmış olsa da bu dersler, farklı programlarda tek tük yer almakta, bazı derslerin ise isimleri farklı olsa da içeriğinin birbirine yakın olduğu görülmektedir.

\section{2.Öğrencilerin Eğitim-Öğretim Dönemlerinde Aldıkları Muhasebe ve Finansman Derslerinin Yeterliliği Konusundaki Görüşlerinin Analizi}

Bu bölümde öncelikle öğrencilere bölümlerin ders programlarında yer alan muhasebefinansman derslerinin yeterliliği konusunda görüşleri sorulmuş, öğrencilerin \% 50,4'ü dersleri yeterli bulmuştur. Daha sonra iki aşamalı olarak gerçekleştirilen analizin ilk aşamasında verilerin frekansları alınıp yorumlanmış, ikinci aşamada çeşitli değişkenler arasındaki ilişkileri ortaya koymak için çapraz tablolar düzenlenip Ki-Kare analizi yapılmıştı.

\subsubsection{Demografik Özellikler ve Muhasebe-Finansman Dersleriyle ilgili Görüşlerin Frekansları}

Öğrencilerin demografik özellikleri, staj yaptıkları yer ile staj süresince muhasebefinansman derslerinden yararlanmaları ve muhasebe-finansman derslerinin okutulma gerekliliği ile önerilen kredilerle ilgili bulguların frekansları alınıp 3 ayrı tablo halinde sunulup yorumlanmıştır.

Tablo 2: Demografik Özellikler ile ilgili Bulgular

\begin{tabular}{|c|c|c|c|}
\hline \multicolumn{2}{|c|}{ Demografik Özellik } & $\mathbf{N}$ & $\%$ \\
\hline \multirow{3}{*}{ Cinsiyet } & $\mathrm{K} 1 \mathrm{z}$ & 60 & 42,6 \\
\hline & Erkek & 81 & 57,4 \\
\hline & Toplam & 141 & 100 \\
\hline \multirow{6}{*}{ Mezun olunan lise } & Düz lise & 59 & 41,8 \\
\hline & Turizm lisesi & 43 & 30,5 \\
\hline & Ticaret lisesi & 3 & 2,1 \\
\hline & Anadolu lisesi & 34 & 24,1 \\
\hline & Diğer & 2 & 1,4 \\
\hline & Toplam & 141 & 100 \\
\hline \multirow{3}{*}{ Bölüm } & Akdeniz Üni.Turizm Fakültesi & 72 & 51,1 \\
\hline & $\begin{array}{l}\text { Alanya A.K.Ü.İşl. Fak. Turizm } \\
\text { İşI.Böl. }\end{array}$ & 69 & 48,9 \\
\hline & Toplam & 141 & 100 \\
\hline \multirow{3}{*}{$\begin{array}{l}\text { Mezuniyetten sonra muhasebeyle } \\
\text { ilgili meslek Seçme veya } \\
\text { muhasebeyle ilgili bölümde çalışma }\end{array}$} & Evet & 58 & 41,1 \\
\hline & Hayır & 83 & 58,9 \\
\hline & Toplam & 141 & 100 \\
\hline
\end{tabular}

Tablo 2'de görüldüğü gibi, öğrencilerin yarısından biraz çoğu erkek (\% 57,4), \% 41,8'i düz lise, \% 30,5'i turizm lisesi mezunu, \% 51,1'i Akdeniz Üniversitesi Turizm Fakültesi'nde öğrenim görmektedir. Öğrencilerin yarısı (\% 50,4), bölümde okutulan muhasebe derslerini 
yeterli görmekte, \% 41,1'i de mezuniyetten sonra muhasebeyle ilgili bir meslek seçmeyi veya muhasebeyle ilgili bir bölümde çalışmayı düşünmektedir.

Tablo 3: Öğrencilerin Staj Yaptıkları yer ve Staj süresince Muhasebe-Finansman Derslerinden Yararlanmaları

\begin{tabular}{|c|c|c|}
\hline Staj Yaptığı Departmanlar & "Evet" (N) & $\%$ \\
\hline Önbüro & 78 & 55,3 \\
\hline Restoran & 74 & 52,5 \\
\hline Bar & 57 & 40,4 \\
\hline Mutfak & 24 & 17,4 \\
\hline İnsan Kaynakları & 18 & 12,8 \\
\hline Housekeeping & 17 & 12,1 \\
\hline Muhasebe & 10 & 7,1 \\
\hline Aktiviteler & 6 & 4,3 \\
\hline Satınalma & 4 & 2,8 \\
\hline Stajda yararlandığı “Muhasebe-Finansman "dersleri & "Evet" (N) & $\%$ \\
\hline Genel Muhasebe & 72 & 51,1 \\
\hline Maliyet Muhasebesi & 34 & 24,1 \\
\hline Finansal Yönetim & 33 & 23,4 \\
\hline Konaklama/Seyahat/Turizm İşl.Muh. & 31 & 22,0 \\
\hline Yatırım Projesi analizi & 19 & 13,5 \\
\hline Finansal Tablolar analizi & 14 & 9,9 \\
\hline Yönetim Muhasebesi & 14 & 9,9 \\
\hline Turizm İşl.Maliyet Kontrolü & 11 & 7,8 \\
\hline Muhasebe Denetimi & 7 & 5,0 \\
\hline
\end{tabular}

Öğrencilerin her bir departmanda staj yapıp yapmadığı ayrı ayrı sorulmuş olup Tablo 3'e göre öğrencilerin en çok staj yaptıkları departmanlar, sırasıyla Önbüro (\% 53,3), Restoran (\% 52,5) ve Bar (\% 40,4)'dır. Staj sırasında en çok yararlandıkları muhasebe-finansman dersleri sırasıyla, Genel Muhasebe (\% 51,1), Maliyet Muhasebesi (\% 24,1), Finansal Yönetim (\% 23,4) ve Konaklama/Seyahat İşletmeleri Muhasebesidir (\% 22,0). Çetin (2005)'in çalışmasında da en çok staj yapılan departmanlar, bu çalışmayla aynı olup Muhasebe dersi, staj sırasında en çok yararlanılan derslerden (5. sırada) biri olmuştur. 
Tablo 4: Öğrencilerin Okutulmasını en çok Gerekli Gördükleri Muhasebe-Finansman Dersleri ve Önerilen Krediler

\begin{tabular}{|l|c|c|c|c|}
\hline \multirow{2}{*}{ Dersler } & Okutulması Gerekir & \multicolumn{3}{|c|}{ Kredi ve Saatleri } \\
\cline { 2 - 5 } & $\%$ & $\mathbf{2}(\%)$ & $\mathbf{3}(\%)$ & $\mathbf{4}(\%)$ \\
\hline Genel Muhasebe & 84,4 & 37,6 & 27,0 & 35,5 \\
\hline Maliyet Muhasebesi & 63,1 & 42,6 & 26,2 & 31,2 \\
\hline Yönetim Muhasebesi & 58,9 & 47,5 & 22,7 & 29,8 \\
\hline Turizm İşı.Maliyet Kontrolü & 58,9 & 51,8 & 22,0 & 26,2 \\
\hline Konaklama/Seyahat/Turizm İşl.Muh. & 57,4 & 48,2 & 24,1 & 27,7 \\
\hline Finansal Yönetim & 56,0 & 48,9 & 25,5 & 25,5 \\
\hline Yatırım Projesi analizi & 55,3 & 51,8 & 27,0 & 21,3 \\
\hline Muhasebe Denetimi & 48,9 & 56,7 & 19,9 & 23,4 \\
\hline Finansal Tablolar analizi & 42,6 & 56,0 & 20,6 & 23,4 \\
\hline
\end{tabular}

Tablo 4'te görüldüğü gibi, öğrencilerin en çok okutulması gerektiğini düşündükleri muhasebe-finansman dersleri, sırasıyla Genel Muhasebe (\% 84,4), Maliyet Muhasebesi (\% 63,1), Yönetim Muhasebesi (\% 58,9) ve Turizm İşletmelerinde Maliyet Kontrolü $(\% 58,9)$ dersleridir. Derslerin ne kadar kredi/saat okutulacağı ile ilgili görüşlerde sadece Genel Muhasebe dersi için görüş bildirilen kredi saat oranı birbirine çok yakın olup diğer muhasebe-finansman derslerinin tamamı için en yüksek tercih oranı açık ara 2 kredi/saat 'tir. Tetik ve Kınay (2007)'ın çalışmasında en çok okutulması gerektiği düşünülen dersler sırasıyla, Konaklama/Seyahat İşletmeleri Muhasebesi, Genel Muhasebe ve Finansal Yönetim'dir.

\subsection{2. Çapraz Tablolar}

Staj sırasında yararlanılan muhasebe-finansman dersleri ile diğer değişkenler arasındaki ve bölümde okutulan muhasebe-finansman derslerinin yeterliliği ile diğer değişkenler arasındaki ilişkileri ortaya koymak için çapraz tablolar düzenlenmiş ve Ki-Kare bilgileri aşağıda tablolar halinde belirtilmiştir. Sadece anlamlı çıkan sonuçlar tablolarda gösterilmiştir.

Tablo 5: Önbüroda Staj Yapma ile Stajda Genel Muhasebe Dersinden Yararlanma iliş̧kisi

\begin{tabular}{|c|c|c|c|c|c|c|c|c|}
\hline \multirow{3}{*}{$\begin{array}{l}\text { Önbüroda Staj } \\
\text { Yapma }\end{array}$} & \multicolumn{4}{|c|}{$\begin{array}{c}\text { Stajda Genel Muhasebe Dersinden } \\
\text { Yararlanma }\end{array}$} & \multicolumn{2}{|c|}{ TOPLAM } & \multirow[t]{2}{*}{$x^{2}$} & \multirow[t]{2}{*}{$\mathbf{P}$} \\
\hline & \multicolumn{2}{|c|}{ Evet } & \multicolumn{2}{|c|}{ Hayır } & & & & \\
\hline & $\mathbf{N}$ & $\%$ & $\mathbf{N}$ & $\%$ & $\mathbf{N}$ & $\%$ & 5,903 & 0,018 \\
\hline Evet & 47 & 60,3 & 31 & 39,7 & 78 & 100 & & \\
\hline Hayır & 25 & 39,7 & 38 & 60,3 & 63 & 100 & & \\
\hline TOPLAM & 72 & 51,1 & 69 & 48,9 & 141 & 100 & & \\
\hline
\end{tabular}


Tablo 5'e göre Önbüroda Staj Yapmış olan öğrencilerin stajları sırasında Genel Muhasebe dersinde öğrendiği bilgiden yararlanıp yararlanmadığını ölçmek için yapılan bu analizde, iki değişken arasında anlamlı bir ilişki bulunmuştur. Önbüroda staj yapanların, stajda Genel Muhasebe Dersinden Yararlanma oranı daha yüksektir.

Tablo 6: Stajda Yararlanılan Muhasebe-Finansman Dersleri ile Bölümde Okutulan Muhasebe Derslerinin Yeterliliği iliş̧kisi

\begin{tabular}{|c|c|c|c|c|c|c|c|c|}
\hline & \multicolumn{4}{|c|}{$\begin{array}{l}\text { Bölümde Okutulan Muhasebe- } \\
\text { Finansman Derslerinin Yeterliliği }\end{array}$} & \multicolumn{2}{|c|}{ TOPLAM } & \multirow[t]{2}{*}{$x^{2}$} & \multirow[t]{2}{*}{$\mathbf{P}$} \\
\hline & \multicolumn{2}{|c|}{ Evet } & \multicolumn{2}{|c|}{ Havır } & & & & \\
\hline Genel Muhasebe'den Yararlanma & $\mathbf{N}$ & $\%$ & $\mathbf{N}$ & $\%$ & $\mathbf{N}$ & $\%$ & 8,682 & 0,004 \\
\hline Evet & 45 & 62,5 & 27 & 37,5 & 72 & 100 & & \\
\hline Hayır & 26 & 37,7 & 43 & 62,3 & 69 & 100 & & \\
\hline TOPLAM & 71 & 50.4 & 70 & 49.6 & 141 & 100 & & \\
\hline Finansal Tablolar Analizi'nden & & & & & & & 4,950 & 0,046 \\
\hline Fvet & 11 & 78.6 & 3 & 21.4 & 14 & 100 & & \\
\hline Hayır & 60 & 47,2 & 67 & 52,8 & 127 & 100 & & \\
\hline TOPLAM & 71 & 50,4 & 70 & 49,6 & 141 & 100 & & \\
\hline Yönetim Muhasebesi'nden & & & & & & & 7,774 & 0,009 \\
\hline Fvet & 12 & 8.5 .7 & 2 & 14.3 & 14 & 100 & & \\
\hline Hayır & 59 & 46,5 & 68 & 53,5 & 127 & 100 & & \\
\hline TOPLAM & 71 & 50,4 & 70 & 49,6 & 141 & 100 & & \\
\hline Yatırım Projeleri Analizi'nden & & & & & & & 4,781 & 0,046 \\
\hline Fvet & 14 & 73.7 & 5 & 26.3 & 19 & 100 & & \\
\hline Hayır & 57 & 46,7 & 65 & 53,36 & 122 & 100 & & \\
\hline TOPLAM & 71 & 50,4 & 70 & 49,6 & 141 & 100 & & \\
\hline
\end{tabular}

Tablo 6'ya göre muhasebe-finansman alanındaki derslerde öğrendikleri bilgilerden staj sırasında yararlandıklarını ifade öğrencilerin, bölümde okutulan muhasebe-finansman derslerini yeterli bulup bulmadıklarını ölçmek için yapılan bu analizde, staj sırasında Genel Muhasebe, Finansal Tablolar Analizi, Yönetim Muhasebesi, Yatırım Projeleri Analizi derslerinde öğrenilen bilgilerden yararlanma ile bölümde Okutulan Muhasebe Derslerinin Yeterliliği arasında anlamlı bir ilişki bulunmaktadır. Söz konusu derslerden yararlananların, bölümde okutulan muhasebe-finansman derslerini yeterli bulma oranı daha yüksektir. 


\section{SONUÇ}

Lisans düzeyinde turizm eğitiminde temel amaç, turizm sektörüne bilgili, yabancı dil bilen, yetkin bireyler yetiştirmektir. Turizmle ilgili eğitim veren lisans düzeyindeki yüksekokul ve fakültelerde öğrenim görenlerin, turizmle ilgili temel bilgiler yanında analiz ve karar vermede gerekli muhasebe ve finansman bilgileriyle donatılmış olarak yetiştirilmeleri gerekir. Bu çalışmanın amacı, Türkiye'de turizmle ilgili eğitim veren lisans düzeyindeki yüksekokul ve fakültelerin ders programlarında yer alan muhasebe ve finansman derslerinin durumunu karşılaştırmalı bir şekilde inceleyerek önerilerde bulunmaktır. Ayrıca turizm sektöründe staj yapmış olan öğrencilerin eğitim-öğretim dönemlerinde aldıkları muhasebe ve finansman derslerinin yeterliliği konusundaki görüşleri analiz edilmiştir.

Staj yapmış öğrencilerin eğitim-öğretim dönemlerinde aldıkları muhasebe ve finansman derslerinin yeterliliği konusundaki görüşlerinden elde edilen sonuca göre öğrencilerin yarısı bölümde okutulan muhasebe derslerini yeterli görmektedir. Öğrencilerin en çok okutulması gerektiğini düşündükleri muhasebe-finansman dersleri, sırasıyla Genel Muhasebe, Maliyet Muhasebesi, Yönetim Muhasebesi ve Turizm İşletmelerinde Maliyet Kontrolü dersleridir. Bu dersler aslında turizmle ilgili eğitim veren kurumların ders programında olması gereken temel derslerdir, ancak Genel Muhasebe haricinde bazı kurumların ders programında yer almamaktadır. Bu derslerde elde edilen bilgilerden staj sırasında da yararlanılacağı düşünüldüğü için öğrencilerin de bu konudaki görüşleri alınmıştır.

Önbüroda staj yapan öğrencilerin, stajda Genel Muhasebe Dersinden Yararlanma oranı daha yüksektir. Staj sırasında Genel Muhasebe, Finansal Tablolar Analizi, Yönetim Muhasebesi, Yatırım Projeleri Analizi derslerinden yararlananların, bölümde okutulan muhasebe-finansman derslerini yeterli bulma oranı daha yüksektir.

Türkiye'de turizmle ilgili eğitim veren lisans düzeyindeki yüksekokul ve fakültelerin ders programlarında yer alan muhasebe ve finansman derslerinin durumu incelendiğinde, ders çeşitliliği artmış olduğu, ancak bu derslerin farklı programlarda tek tük yer aldığı, bazı derslerin ise isimleri farklı olsa da içeriğinin birbirine yakın olduğu, ayrıca muhasebefinansmanla ilgili temel derslerin bir kısmının genel olarak programlarda yer aldığı, ancak eskiye göre daha iyi olsa da karar almaya yönelik derslerin halen yeterli olmadığı görülmektedir. Nitekim, bazı büyük zincir otellerin üst düzey yöneticileriyle yapılan görüşmelerde, finansal tabloların nasıl okunup yorumlanacağı ve değerlendirme yapılacağı sorularına yanıt verecek derslere ihtiyaç olduğu dile getirilmiştir. Dolayısıyla bu derslerin en azından seçmeli ders olarak bile programa koyulması sektör ihtiyacını karşılayacaktır. Turizmle ilgili lisans düzeyinde eğitim veren bölümlerin ders programları düzenlenirken veya güncellenirken, muhasebe ve finansman bilgisinin önemi göz önünde bulundurulup finansal tabloların anlaşılıp yorumlanabilmesi, yiyecek-içecek maliyetlerinin kontrolü, paket tur maliyetlerinin hesaplanması, bütçe oluşturma, maliyet-kara geçiş analizlerinin sağıklı yapılabilmesi için Genel Muhasebe dersi alındıktan sonra özellikle Konaklama/Iş̧letmeleri Muhasebesi, Maliyet Muhasebesi, Yönetim Muhasebesi, Finansal Tablolar Analizi ve Turizm İşletmelerinde Maliyet Kontrolü dersleri, turizmle ilgili lisans eğitimi veren yüksekokul ve fakültelerin ders programlarında yer almalıdır. 


\section{KAYNAKÇA}

Akoğlan Kozak ve M., Kozak, N. (2000), Türkiye'de Lise, Önlisans ve Lisans Düzeyindeki Seyahat Acenteciliği Programlarında Okutulan Derslerin Sektörün Beklentilerine Uygunluğu, Anatolia:Turizm Araştırmaları Dergisi, 11(Eylül-Aralık): 57-67.

Akoğlan Kozak, M. (2009), Akademik Turizm Eğitimi üzerine bir Durum Analizi, Muğla Üniversitesi Sosyal Bilimler Enstitüsü Dergisi, 22: 1-20

Christou, E. S. (1999), Hospitality Management Education In Greece: An Exploratory Study, Tourism Management,20(6): 683-691.

Chung, K. Y. (2000), Hotel management curriculum reform based on required competencies of hotel employees and career success in the hotel industry, Tourism Management, 21: 473-487.

Çetin, Ş. (2005),Öğrenci Stajlarında Yararlanılan Dersler Üzerine Ampirik Bir Değerlendirme: Mersin Turizm İşletmeciliği ve Otelcilik Yüksekokulu Örneği, Anatolia: Turizm Araştırmaları Dergisi, 16(2): 153-169.

Gürbüz, A. K. ve Dağdeviren, A. (2007), Lisans Düzeyinde Turizm Eğitimi Veren Kurumların Ders Programlarının Fonksiyonel Açıdan İncelenmesi, Balıkesir Üniversitesi Sosyal Bilimler Enstitüsü Dergisi, 10(18): 157-167.

Subaşı Ş. ve Demir, B. (2009), Fakültelerin İşletme Bölümlerinde Verilen Muhasebe Derslerinin Durum Analizi, Muhasebe ve Finansman Dergisi, 44(4): 127-136.

Tetik, N. ve Kınay, F. (2007), Lisans Düzeyinde Turizm Eğitimi Veren Okullarda, Muhasebe-Finans Eğitimine Verilen Önem ile Eğitimin Yeterliliği Konusunda bir Araştırma, Muhasebe Bilim Dünyası Dergisi, 9(3): 1-18.

Türkeri, İ. (2014), Yükseköğretim Düzeyinde Turizm Eğitiminin Özel Nitelikli Sorunları Ve Çözüm Önerileri, Mehmet Akif Ersoy Üniversitesi Eğitim Bilimleri Enstitüsü Dergisi, 3(4): 1-14

Uyar, S. Ve Yelgen, E. (2012), Konaklama İşletmelerinin Muhasebe Eğitiminden Beklentileri, Trakya Üniversitesi Sosyal Bilimler Dergisi, 14(2): 327-348.

Wang, J., Ayres, H. Ve Huyton, J. (2010), Is Tourism Education Meeting the Needs of the Tourism Industry? An Australian case study. Journal of Hospitality \& Tourism Education, 22(1): 8-14. 